\title{
In vivo characterisation of the Golgi matrix protein giantin: linking extracellular matrix secretion and cilia function
}

\author{
D Bergen ${ }^{1 *}$, D Asante ${ }^{1}$, N Stevenson ${ }^{1}$, P Verkade ${ }^{1,2,3}$, C Hammond $^{1,2}$, D Stephens ${ }^{1}$ \\ From Cilia 2014 - Second International Conference \\ Paris, France. 18-21 November 2014
}

The C-terminal anchored golgin giantin (golgb1) plays a crucial role in Golgi structure and acts as a tether for COPI vesicles at the cis-and-medial Golgi. Recently, our lab has shown that in addition to its known roles in membrane trafficking, giantin is required for ciliogenesis in vitro. A functional knockout of giantin exists. The osteochondrodysplasia rat, that arose from a spontaneous insertion in the golgb1 gene. Homozygous embryos depicted severe craniofacial defects and oedema, caused by defects in extracellular matrix composition. However, ex vivo cultured skin fibroblasts from these animals showed no major ciliogenesis defects. To further elucidate the role of giantin in extracellular matrix and cilia function we have used morpholino knockdown in the zebrafish. Knockdown resulted in a curly tail down and tail tip up phenotype with severe cardiac oedema, hydrocephalus, and craniofacial defects in the pharyngeal craniofacial structures. Immunohistochemistry revealed that collagen-2 expression was altered in an ectopic fashion in these structures. Furthermore, defects in cilia function were observed. In the neural tube cilia number was reduced and visible cilia were longer. Additionally, morphants showed randomisation of the heart position, suggesting left-right patterning is affected. This work is strongly implying a dual role for giantin in extracellular matrix deposition and cilia function.

\section{Authors' details}

${ }^{1}$ School of Biochemistry, University of Bristol, Bristol, UK. ${ }^{2}$ School of Physiology and Pharmacology, University of Bristol, Bristol, UK. ${ }^{3}$ Wolfson Bioimaging Facility, University of Bristol, Bristol, UK.

${ }^{1}$ School of Biochemistry, University of Bristol, Bristol, UK

Full list of author information is available at the end of the article
Published: 13 July 2015

doi:10.1186/2046-2530-4-S1-P38

Cite this article as: Bergen et al:: In vivo characterisation of the Golgi matrix protein giantin: linking extracellular matrix secretion and cilia function. Cilia 2015 4(Suppl 1):P38.
Submit your next manuscript to BioMed Central and take full advantage of:

- Convenient online submission

- Thorough peer review

- No space constraints or color figure charges

- Immediate publication on acceptance

- Inclusion in PubMed, CAS, Scopus and Google Scholar

- Research which is freely available for redistribution
C Bïomed Central 